\title{
TRANSFORMASI DOKUMEN KOMUNIKASI VISUAL SAMPUL BUKU DIGITAL DALAM METODE PENELITIAN KUALITATIF PERSPEKTIF SOSIAL BUDAYA BIDANG DESAIN KOMUNIKASI VISUAL
}

\author{
Sujud Puji Nur Rahmat \\ Program Studi Desain Komunikasi Visual, Fakultas Desain dan Seni Kreatif \\ Universitas Mercu Buana \\ Jl. Meruya Selatan No. 1, Kecamatan Kembangan, Kota Jakarta Barat, Kode Pos 11650 \\ DKI Jakarta, Indonesia \\ Email: sujud.puji@mercubuana.ac.id
}

\begin{abstract}
Abstrak
Pada dokumen komunikasi visual terdapat jenis sampul buku berisi informasi yang bisa diperoleh dan dianalisis seorang peneliti. Sebelum adanya teknologi bersumber internet, masyarakat hanya berkomunikasi secara fisik atau tatap muka sehingga dokumen komunikasi visual sampul buku yang diperoleh seorang peneliti juga berbentuk fisik. Metode komunikasi masyarakat kini berubah, dengan menggunakan teknologi bersumber internet yang menyediakan layanan jasa komunikasi visual berbasis aplikasi media sosial, seperti Whatsapp, Facebook, dan Tokopedia. Metode komunikasi masyarakat yang berubah memengaruhi bentuk dokumen komunikasi visual sampul buku dalam penelitian kualitatif, awalnya fisik kini bertransformasi menjadi digital. Melalui Whatsapp, Facebook, dan Tokopedia, seorang peneliti melakukan pengambilan data dokumen komunikasi visual sampul buku digital. Metode penelitian pada tulisan ini, menggunakan metode penelitian campuran antara, pertama, etnografi konvensional dan, kedua, etnografi virtual sebagai cara penyelidikan melalui observasi dan pemeriksaan dokumen komunikasi visual sampul buku fisik maupun digital pada objek penelitian dengan tujuan untuk mendapatkan data-data yang diperlukan. Berdasarkan hasil analisis, terdapat satu fenomena lama, yaitu (1) dokumen komunikasi visual sampul buku fisik; dan terdapat dua fenomena baru, yaitu (1) dokumen komunikasi visual sampul buku fisik yang didokumentasikan dengan cara digandakan berbentuk digital dan (2) dokumen komunikasi visual sampul buku digital. Terdapat fenomena lainnya, yaitu transformasi dokumen komunikasi visual sampul buku digital memengaruhi karakter subjek peneliti, prosedur serta proses dalam teknik pengambilan data, dan mengubah serta menambah khazanah teoretis pada metode penelitian kualitatif.
\end{abstract}

Kata Kunci: transformasi digital, teknik pengumpulan data.

\begin{abstract}
The use of visual communication documents is one of the data collection techniques, in addition to interviews and observations, in a research method conducted by a researcher. In visual communication documents, there is a type of book cover containing information that a researcher can obtain and analyze. Before the existence of internet-sourced technology, people only communicated physically or face-to-face so that the visual communication document for the book cover obtained by a researcher was also physical. Community communication methods are now changing, using internet-sourced technology that provides visual communication services based on social media applications, such as Whatsapp, Facebook, and Tokopedia. Changing community communication methods affect the form of book cover visual communication documents in qualitative research, initially physically now transforming into digital. Through Whatsapp, Facebook, and Tokopedia, a researcher collected data on visual communication documents on digital book covers. The research method in this paper uses a mixed research method, first, conventional ethnography and, second, virtual ethnography as a way of investigation through observation and examination of physical and digital book cover visual communication documents on the object of research in order to obtain the necessary data. Based on the analysis, there is one old phenomenon, namely (1) visual communication documents on physical book covers; and there are two new phenomena, namely (1) physical book cover visual communication documents which are documented by means of digital copies and (2) digital book cover visual communication documents. There is another phenomenon, namely the transformation of the digital book cover visual communication document affecting the character of the research subject, the procedures and processes in data collection techniques, and changing and adding to the theoretical repertoire of qualitative research methods.
\end{abstract}

Keywords: digital transformation, data collection technique. 


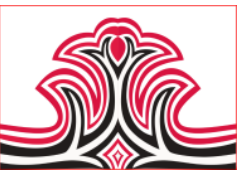

\section{PENDAHULUAN}

Dokumen digunakan sebagai teknik pengumpulan data dalam metode penelitian kualitatif. Dokumen yang digunakan berisi informasi yang bisa diperoleh dan dianalisis sehingga menjadi data sebagai pendukung penelitian kualitatif pada objek penelitian tertentu bagi seorang peneliti. Berdasarkan hasil analisis, maka diperoleh sebuah pernyataan atau jawaban atas pertanyaan penelitian ilmiah yang selanjutnya dipublikasikan sebagai argumentasi teoritis bagi seorang peneliti. Dokumen tidak hanya memberikan sebuah informasi, tetapi juga menentukan arah kebijakan hasil penelitian kualitatif. Kata dokumen berasal dari Bahasa latin, yaitu docere, yang berarti mengajar (Anggito dan Setiawan, 2018). Sedangkan, penelitian adalah sebuah proses kegiatan mencari kebenaran terhadap suatu fenomena ataupun fakta yang terjadi dengan cara yang terstruktur dan sistematis (Karmanis \& Karjono, 2020).

Dokumen yang digunakan dalam penelitian kualitatif sebagai metode pengumpulan data berbentuk audio, video (audio dan visual), dan komunikasi visual. Pada dokumen komunikasi visual bermacam bentuk, jenis, fungsi, penempatan, dan sumber yang bercabangcabang. Komunikasi visual menggunakan Bahasa visual, dengan unsur dasar Bahasa visual menjadi kekuatan utama dalam penyampaian pesan (Putra, 2020). Dokumen komunikasi visual, terdapat dua bentuk, yaitu rahasia dan publikasi. Dokumen komunikasi visual rahasia, terdapat dua sumber, yaitu dari negara dan rahasia perusahaan atau perseorangan. Pengertian dokumen komunikasi visual rahasia bersumber dari negara dan perusahaan atau perseorangan, seperti surat tanah, surat medis, pembukuan keuangan, notulen rapat, dan sebagainya. Lebih lanjut kaitan antara dokumen dan penelitian, Gottschalk menyatakan bahwa dokumen dalam pengertiannya yang lebih luas berupa setiap proses pembuktian yang didasari atas jenis sumber apapun, baik itu bersifat, lisan, gambaran, atau arkeologis (Anggito dan Setiawan, 2018).

Pada bentuk dokumen komunikasi visual publikasi, terdapat tiga bentuk, yaitu statis, video (audio dan visual), dan multimedia (audio, visual, grafis, dan teks). Dokumen komunikasi visual publikasi statis, video, dan multimedia, terdapat dua sumber, yaitu dari negara dan perusahaan atau perseorangan. Bentuk dokumen komunikasi visual publikasi statis fisik, terdapat 3 wujud, yaitu tertulis atau manual media kertas; pahat simbol dan gambar media kayu dan batu; dan perancangan komunikasi visual media kertas dan media untuk spanduk, papan iklan, dan sebagainya. Pada
Gorga : Jurnal Seni Rupa

Volume 10 Nomor 01 Januari-Juni 2021

p-ISSN: 2301-5942 | e-ISSN: 2580-2380

bentuk dokumen komunikasi visual publikasi statis fisik perancangan komunikasi visual media kertas yang umumnya digunakan untuk jenis poster dan sampul buku. Pada sampul buku, umumnya terdapat elemenelemen desain, sepert ilustrasi (gambar), fotografi, tipografi dan huruf, komposisi, warna, dan lay-out. Desain komunikasi visual adalah ilmu yang mempelajari konsep komunikasi ... yang diaplikasikan dalam pelbagi media komunikasi visual dengan megelola elemen desain grafis yang terdiri tas gambar (ilustrasi), huruf dan tipografi, warna, komposisi, warna, dan layout (Tinarbuko, 2012).

Transformasi sosial selalu dan akan terjadi di tengahtengah kehidupan masyarakat dunia termasuk Indonesia. Transformasi sosial yang terjadi pada saat ini, adalah transformasi digital. Tranformasi digital dalam hal ini, utamanya adalah informasi dan komunikasi berbentuk digital yang didasari dengan teknologi bersumber internet yang menyediakan layanan jasa komunikasi visual berbasis aplikasi media sosial, seperti Whatsapp, Facebook, dan Tokopedia. Transformasi pernah serta sering terjadi sehingga memiliki pola pembentukan tersendiri. Transformasi dibayangkan sebagai proses tawar-menawar secara dialektis yang bekelanjutan untuk kemudian dibayangkan akan terjadi transformasi akhir, besar, dan langgeng (Sachri \& Sunarya, 2001).

Kata transformasi berasal dari bahasa latin "transformare", yang artinya mengubah bentuk.... Pengertian mengenai istilah transformasi ..., pertama, transformasi berkaitan dengan pengertian yang menyangkut perubahan mendasar berskala besar dalam masyarakat dunia, yang beralih dari tahap masyarakat industri menjadi masyarakat informasi (Mahmudiin, 2017). Transformasi sosial dapat mengandung arti proses perubahan atau pembaharuan struktur sosial, sedangkan di pihak lain menegandung makna proses perubahan atau pembaharuan nilai.... perubahan sosial adalah transformasi dalam organisasi masyarakat, dalam pola pikir dan dalam perilaku pada waktu tertentu (Mahmudiin, 2017).

Pada penggunaan teknologi bersumber internet yang menyediakan layanan jasa komunikasi visual berbasis media sosial, seperti Whatsapp, Facebook, dan Tokopedia, terjadi interaksi antar-masyarakat pengguna, sehingga tercipta masyarakat sosial internet. Masyarakat sosial pengguna internet atau yang disebut dengan netizen. Netizen terdiri dari gabungan kata internet dan citizen (warga), yang seringkali diartikan sebagai "warga-nya internet". Jadi, yang biasanya disebut sebagai netizen adalah orang-orang yang secara 
aktif terlibat di komunitas online, atau internet secara umum (Sakti, 2020). Adapun tema pembahasan komunikasi antar-netizen bervariasi. Situs jejarng sosial maya internet memungkinkan penggunanya berbagi ide, gagasan, pandangan, informasi, dan pengalaman hidupnya melalui layanan yang disedikan (Pratama, 2017).

Pada era transformasi digital seperti saat ini, segala sesuatu aktivitas dilakukan secara digital online. Terdapat dua faktor peristiwa dunia yang mendorong penggunaan teknologi bersumber internet yang menyediakan layanan jasa komunikasi visual berbasis media sosial, seperti Whatsapp, Facebook, dan Tokopedia. Pertama, bisnis merupakan salah satu utama sebagai pendorong terciptanya komunikasi antar-masyarakat, baik nasional maupun internasional, menggunakan informasi dan komunikasi digital. Transformasi digital sering digunakan untuk meningkatkan ketangkasan dan efisiensi operasional, transformasi menjadi mungkin (Sas, 2021). Kedua, pada saat kondisi pandemi virus Covid-19, digunakan oleh pemerintah Indonesia sebagai alasan untuk pendorong transformasi digital di Indonesia. Kominfo melalui agenda utamanya adalah, meningkatkan literasi digital, menciptakan ekosistem digital yang lebih produktif, (Andarningtyas, 2020). Mengenai kondisi Indonesia dan seluruh dunia, pandemi Covid-19 sudah merebak ke seluruh dunia sejak Januari 2020 silam. Indonesia sendiri mulai terinfeksi pada Maret 2020 (Maulaa, 2020).

Pada tulisan ini, merupakan hasil penelitian yang menganalisis dokumen perancangan komunikasi visual publikasi statis fisik dari media berbentuk kertas bertransformasi menjadi digital yang digunakan untuk sampul buku yang bersumber dari perusahaan atau perseorangan. Pada jenis sampul buku, terdapat unsurunsur yang mendukung pengertian desain grafis atau desain komunikasi visual. Segala sesuatu pertukaran informasi, komunikasi, bahkan transaksi yang dilakukan sebagian masyararakat Indonesia, sudah menggunakan teknologi bersumber internet yang menyediakan layanan jasa komunikasi visual berbasis media sosial, seperti Whatsapp, Facebook, dan Tokopedia.

Topik ini sangat penting karena menjelaskan tentang penentuan mengenai peta penelitian, mulai dari rencana, pelaksanaan, dan hingga hasil pada era transformasi digital seperti saat ini. Dokumen komunikasi visual sampul buku merupakan bagian dari penentuan mengenai peta penelitian. Seorang peneliti akan membahas dokumen komunikasi visual sampul
Gorga : Jurnal Seni Rupa

Volume 10 Nomor 01 Januari-Juni 2021

p-ISSN: 2301-5942 | e-ISSN: 2580-2380

buku mulai dari rencana, pelaksanaan, dan hingga hasil penelitian. Peta penelitian era transformasi digital seperti saat ini berbeda dengan peta penelitian era sebelumnya yang hanya berbentuk fisik. Di mana peta penelitian era sebelumnya, hanya terdapat jenis dokumen komunikasi visual sampul buku fisik saja. Namun, dokumen komunikasi visual sampul buku digital bukan satu-satunya sebagai objek penelitian kualitatif bidang desain komunikasi visual di era transformasi digital seperti saat ini. Dokumen komunikasi visual sampul buku fisik juga masih ada dan dapat dijadikan teknik pengumpulan data oleh seorang peneliti.

Tujuan penulisan ini, mengkaji dokumen komunikasi visual sampul buku fisik yang terdapat di ruang fisik dan transformasi dokumen komunikasi visual sampul buku digital pada teknologi bersumber internet yang menyediakan layanan jasa komunikasi visual berbasis media sosial, seperti Whatsapp, Facebook, dan Tokopedia sebagai teknik pengumpulan data dalam metode penelitian kualitatif perspektif sosial budaya bidang desain komunikasi visual. Pengkajian dokumen komunikasi visual sampul buku fisik yang terdapat di ruang fisik sebagai teknik pengumpulan data dalam metode penelitian kualitatif perspektif sosial budaya bidang desain komunikasi visual dalam penulisan ini, dimanfatkan sebagai teknik pembanding dengan dokumen komunikasi visual sampul buku digital. Pembandingan terdiri dari, mulai dari karakter subjek penelitian, prosedur serta proses teknik pengmpulan data, dokumen komunikasi visual sampul buku, baik fisik maupun digital. Karaker subjek penelitian merupakan siapa pelaku pengguna teknologi bersumber internet yang menyediakan layanan jasa komunikasi visual berbasis media sosial, seperti Whatsapp, Facebook, dan Tokopedia. Prosedur merupakan teknik pencarian dokumen komunikasi visual sampul buku, baik fisik maupun digital. Proses merupakan teknik pengumpulan dan pemindahan dokumen komunikasi visual sampul buku, baik fisik maupun digital, ke ruang atau tempat penyimpanan yang lain.

\section{KAJIAN TEORI}

\section{Meneropong Teori Budaya Transformasi di Indonesia}

Meninjau jauh kebelakang terkait wacana transformasi dan Indonesia dalam pandangan akademisi sudah pernah terjadi sejak dahulu hingga era transformasi digital pada Generasi Z seperti saat ini. Wacanawacana tersebut antara lain transformasi dan Indonesia dalam kaitan dengan budaya, sosial, teknologi secara kaidah-kaidah akademis pernah disampaikan pada 
tahun 1989 hingga era transformasi digital pada Generasi Z seperti saat ini. Transformasi terkait historis, perdagangan atau bisnis, teknologi, industri, nilai-nilai, kesehatan atau pandemi, dan hukum.

Umar Kayam, akademisi tersebut yang menyampaikan wacana transformasi dan Indonesia dalam kaitan dengan budaya. Transformasi dan Indonesia dalam pandangan budaya, dibahas secara mendalam dengan menggunakan pendekatan historis. Selain Umar Kayam, akademisi lain yang juga membahas wacana transformasi kesenirupaan Indonesia dalam kaitan dengan budaya, adalah Agus Schari dan Yan Yan Sunarya, dengan menggunakan pendekatan historis. Transformasi, Indonesia, dan keseniruapaan Indonesia terkait historis berdasarakan sumber daya alam, perdagangan/bisnis menggunakan kapal besar dengan bangsa besar, seperti Cina, India, dari berbagai profesi, seperti pendeta Hindu dan Budha yang ditandai dengan Sriwijaya dan Borobudur. Tranformasi yang terjadi adalah sistem kepercayaan. Selain itu, tranformasi kebudayaan, yang juga ditandai dengan kerajaan Singsari, kerajaan Majapahit, kebudayaan Islam, datangnya penjajah Portugis, Inggris, Belanda, Jepang, dan terciptanya Nasionalisme (Sachri \& Sunarya, 2001).

Transformasi berdasarkan sosial terkait yang ditawarkan teknologi. Transformasi sosial, menurut teori Toffler, kekuatan di balik transformasi yang mendorong perubahan tersebut, satu di antara empat pendorong adalah kemungkinan yang ditawarkan oleh teknologi baru (Mahmudiin, 2017). Transformasi berdasarkan sosial dan budaya terkait kondisi pandemi dan pemanfaatan penggunaan teknologi sebagai solusi alternatif agar masyarakat tetap beraktivitas dan produktif. ... salah satu cara merespons krisis yang awalnya adalah krisis medis berupa pandemi yang kemudian berdampak pada krisis sosial ... dan lain-lain yang kemudian memaksa kita membangun budaya baru, tradisi baru berupa hidup dengan lebih sehat misalnya atau melakukan kegiatan produktif dengan teknologi (Nugroho, 2020). Tranformasi berdasarkan sosial budaya terkait industri, nilai-nilai, dan hukum. Pengalaman Indonesia yang panjang dalam transformasi sosial budaya bermaksud mengubah keadaan sosial budaya itu sendiri, tujuannya adalah keadaan dan kehidupan yang lebih baik melalui kegiatan dan aktivitas hidup berdasarkan tingkat peradabannya (Kistanto, 2018).

\section{Transformasi Metode Penelitian Kualitatif}

Budaya transformasi selalu dilakukan masyarakat Indonesia dari berbagai kondisi dan situasi. Cakupan kerangka teori tulisan ini, membahas budaya transformasi sosial digital dalam kaitan dengan teknik pengumpulan data dalam metode penelitian kualitatif. Teknik pengumpulan data dalam metode penelitian kualitatif dari fisik bertransformasi menjadi digital memiliki tata-cara dan nilai tersendiri sehingga menjadi sosial budaya terbaru. Seorang peneliti dalam penelitian kualitatif, khususnya bidang desain komunikasi visual, memerlukan kepekaan yang mendalam terkait dengan transformasi sosial yang berdampak pada teknik pengumpulan data.

Transformasi sosial yang berdampak pada teknik pengumpulan data, memengaruhi tujuh paradigma bagi seorang peneliti kualitatif dalam merencanakan, melaksanakan, dan hasil dari penelitian yang dilakukannya. Pertama, seorang peneliti harus memahami betul rencana dan lapangan penelitian pada media virtual yang digunakan masyarakat sebagai objek penelitiannya. Kedua, seorang peneliti harus memahami betul media virtual komunikasi yang digunakan masyarakat sebagai objek penelitiannya. Ketiga, seorang peneliti harus memahami betul materi komunikasi di media virtual yang dibahas masyarakat sebagai objek penelitiannya. Keempat, seorang peneliti harus memahami betul karakter media komunikasi virtual tyang digunakan masyarakat sebagai objek penelitiannya. Kelima, seorang peneliti harus memahami betul memasuki dan berinteraksi di media komunikasi virtual yang digunakan masyarakat sebagai objek penelitiannya. Keenam, seorang peneliti harus memahami betul teknik pengumpulan data yang didapat dari observasi, wawancara, dan dokumen di media virtual yang digunakan masyarakat di sebagai objek penelitiannya. Ketujuh, seorang peneliti harus memahami betul teknik pemindahan data yang didapat dari media virtual ke media yang lain sehingga menjadi data yang bisa dianalisis.

Pada objek penelitian kualitatif bidang desain komunikasi visual, yang keseluruhannya terkait dan bersentuhan dengan gambar, terutama sampul buku. Gambar sampul buku, tidak hanya sebagai dokumen semata, tetapi juga sebagai objek observasi yang tidak bisa berbicara dan diwawancarai. Gambar-gambar sampul buku, kini bertransformasi dari fisik menjadi digital sehingga memerlukan pengetahuan yang luas bagi seorang peneliti kualitatif terhadap media komunikasi visual virtual. Dalam penelitian visual data gambar haruslah selalu ada, dan data visual inilah yang menjadi modal pertama dan utama, karena dari mengamati data visual akan timbul pertanyaanpertanyaan mendapatkan data visual diperlukan kegiatan perekaman (Soewardikoen, 2019). 


\section{METODE PENELITIAN}

Pada penulisan ini, menggunakan dua metode penelitian, yaitu etnografi konvesional dan etnografi virtual. Kedua metode penelitian tersebut, digunakan untuk mendapatkan, mengumpulkan, dan menganalisis data-data yang dianggap perlu dalam penulisan ini. Selain itu, kedua metode penelitiam tersebut, digunakan sebagai pembanding dan koherensi konsep pada objek penelitian yang sama, yaitu dokumen komunikasi visual sampul buku perspektif sosial budaya bidang desain komunikasi visual. Metode penelitian adalah suatu cara atau proses ilmiah dengan tujuan memperoleh data dengan kegunaan dan tujuan tertentu (Karmanis \& Karjono, 2020).

Melalui kedua metode penelitian tersebut, yaitu etnografi konvesional dan etnografi virtual, penulis melakukan observasi partisipan. Terkait observasi, menurut Adler, menyebutkan bahwa observasi merupakan salah satu dasar fundamental dari semua metode pengumpulan data dalam penelitian kualitatif, khususnya menyangkut ilmu-ilmu sosial dan perilaku manusia (Hasanah, 2016). Terkait patisipan, terdiri dari empat tipe pengamat (observe), pertama, menjadi pengamat penuh (complete participation); kedua, partisipan sebagai pengamat (participant as observer); ketiga, pengamat sebagai partisipan (observer as participant); keempat, menjadi pengamat penuh (complete observer) (Hasanah, 2016).

Pada pengertian metode penelitian etnografi konvensional, etnografi juga berarti kajian untuk mendeskripsikan perilaku kelompok sosial tertentu. Kegiatan etnografi difokuskan pada perilaku budaya oleh kelompok sosial, melihat bagaimana kehidupan sehari-hari yang dilakukan oleh kelompok tersebut sebagai subjek yang diteliti (Wasitaatmadja, 2020). Sedangkan pada pengertian metode penelitian etnografi virtual, etnografi virtual merupakan metode etnografi yang dilakukan untuk melihat fenomena sosial dan/atau kultur pengguna di ruang siber. Pendekatan etnografi virtual merujuk pada artefak yang ada di ruang siber dan artefak itulah yang nantinya akan dideskripsikan dan dianalisis (Nasrullah, 2016).

\section{HASIL DAN PEMBAHASAN}

\section{Hasil}

Pengertian sebuah dokumen bersifat relatif dalam penelitian kualitatif. Dokumen dipandang serta diperoleh dengan teknik pengumpulan data tertentu, dan diolah serta dianalisis melalui metode penelitian tertentu. Melalui teknik pengumpulan data dan metode penelitian tertentu, sebuah dokumen akan memberikan sebuah informasi yang diperlukan. Berbeda peneliti, maka sebuah benda relatif akan dianggap menjadi dokumen penelitian atau bukan. Peneliti perlu memiliki kepekaan teoritik untuk memaknai semua dokumen tersebut sehingga tidak sekedar barang yang tidak bermakna (Anggito dan Setiawan, 2018).

Dokumen yang diperlukan dalam penelitian kualitatif adalah dokumen yang relevan dengan fokus penelitian dan dibuktikan untuk melengkapi data. Bagi seorang peneliti kualitatif bidang desain komunikasi visual, dokumen yang terdapat elemen desain grafis, desain komunikasi visual, dan sebagainya yang masih terkait merupakan pencarian utama data sebagai teknik pengumpulan data dalam metode penelitian. Dokumen yang terdapat elemen desain grafis, desain komunikasi visual, dan sebagainya yang masih terkait selanjutnya dikumpulkan melalui atau dari karakter subjek penelitian, prosedur, dan proses dalam penelitian di ruang fisik maupun virtual melalui etnografi konvesional dan etnografi virtual. Mengenai karakter subjek penelitian, prosedur, dan proses selanutnya dijelaskan melalui (1) Karakter Penyebaran Tampilan Sampul Buku Fisik dan Digital; (2) Karakter Subjek, Prosedur, dan Proses Penelitian di Ruang Fisik dan Virtual; dan (3) Karekter Bentuk Dokumen Komunikasi Visual Sampul Buku Fisik dan Digital.

\section{1). Karakter Penyebaran Tampilan Sampul Buku Fisik dan Digital}

Pada karakter penyebaran tampilan sampul buku yang sebelum menjadi dokumen komunikasi visual terdiri dari tiga fenomena penyebaran, yaitu (1) dokumen komunikasi visual sampul buku fisik, (2) dokumen komunikasi visual sampul buku fisik yang didokumentasikan dengan cara digandakan berbentuk digital, dan (3) dokumen komunikasi visual sampul buku digital. Pada masing-masing karakter penyebaran, memiliki kerangka atau prosedur tersendiri. Pada dokumen komunikasi visual sampul buku fisik, merupakan karakter yang pertama dan telah lama terjadi. Pada dokumen komunikasi visual sampul buku fisik yang didokumentasikan dengan cara digandakan berbentuk digital dan dokumen komunikasi visual sampul buku digital, merupakan karakter yang terbaru. Pada proses ketiga, dokumen komunikasi visual sampul buku digital, berhenti sampai diidesain karena bisa dipublikasikan langsung di media sosial yang berbabasis digital. 
Desain Sampul Buku Termasuk Isinya Berbentuk Digital

Dicetak untuk Dijadikan Buku Fisik

Disebar untuk Dijual atau Dibagikan Kepada Penjual,

Perpustakaan, Toko Buku, dan Perseorangan

Peneliti Mendapatkan Sampul Buku Sebagai

Dokumen untuk Dianalisis dan Disimpan

Bagan 1. Kerangka Gambaran Karakter Penyebaran Sampul Buku dan Dijadikan Dokumen Komunikasi Visual Sampul Buku Fisik

dalam Rencana Penelitian Lapangan Untuk Seorang Peneliti Kualitatif.

Bagan: Sujud Puji Nur Rahmat, Yogyakarta, 29 Mei 2021.

Desain Sampul Buku Termasuk Isinya Berbentuk Digital

Dicetak untuk Dijadikan Buku Fisik

Disebar untuk Dijual atau Dibagikan Kepada Penjual,

Perpustakaan, Toko Buku, dan Perseorangan

Sampul Buku Fisik Digandakan Berbentuk Digital

Oleh Penjual, Perpustakaan, Toko Buku, dan

Perseorangan yang Didokumentasikan dengan Cara

Digandakan Berbentuk Digital dan Disebar di

Whatsapp, Facebook, dan Tokopedia

Peneliti Mendapatkan Sampul Buku Digital di

Whatsapp, Facebook, dan Tokopedia Sebagai

Dokumen untuk Dianalisis dan Disimpan.

Bagan 2. Kerangka Gambaran Karakter Penyebaran Sampul Buku Fisik yang Didokumentasikan dengan Cara Digandakan Berbentuk Digital dan Dijadikan Dokumen Komunikasi Visual Sampul Buku Digital dalam Rencana Penelitian Lapangan Untuk Seorang Peneliti Kualitatif.

Bagan: Sujud Puji Nur Rahmat, Yogyakarta, 29 Mei 2021

Desain Sampul Buku Termasuk Isinya Berbentuk Digital

Disebar untuk Dipromosikan yang Selanjutnya Dijual

Oleh Penerbit Buku Kepada Calon Pembeli di Whatsapp, Facebook, dan Tokopedia

Peneliti Mendapatkan Sampul Buku Digital di Whatsapp, Facebook, dan Tokopedia Sebagai

Dokumen untuk Dianalisis dan Disimpan

Bagan 3. Kerangka Gambaran Karakter Penyebaran Sampul Buku Digital dan Dijadikan Dokumen Komunikasi Visual Sampul Buku
Gorga : Jurnal Seni Rupa

Volume 10 Nomor 01 Januari-Juni 2021

p-ISSN: 2301-5942 | e-ISSN: 2580-2380

Digital dalam Rencana Penelitian Lapangan Untuk Seorang Peneliti Kualitatif.

Bagan: Sujud Puji Nur Rahmat, Yogyakarta, 29 Mei 2021

2). Karakter Subjek, Prosedur, dan Proses Penelitian di Ruang Fisik dan Virtual

Sampul buku merupakan bagian objek penelitian yang dikaji para peneliti bidang desain komunikasi visual. Pada tulisan ini, sampul buku merupakan sebagai objek wacana tranformasi dokumen komunikasi visual digital perspektif sosial budaya. Terdapat perbedaan antara karakter subjek, prosedur, dan proses dalam penelitian di ruang fisik maupun virtual. Terkait karakter subjek pelaku yang dijadikan bahan penelitian: (1) pada fisik: cenderung ciri usia tua dan tinggal di pedesaaan yang tidak didukung fasilitas internet dengan cara berkomunikasi tatap muka, bekenalan dengan cara berbasa-basi dan berjabat tangan; (2) pada virtual: cenderung ciri usia muda dan tinggal di perkotaan yang didukung dengan fasilitas internet dengan cara komunikasi jarak jauh, berkenalan dengan menekan tombol "tambah teman", menambah nomor handphone, atau memeliki akun Tokopedia.

Terkait prosedur, letak buku berada: (1) pada fisik: mendatangi tempat-tempat penyimpanan buku, seperti rumah kolektor buku, perpustakaan di instansi pemerintah maupun swasta, toko buku, pemilik buku; meminta izin untuk melihat dan mengambil gambar sampul buku; (2) pada virtual: menekan tombol "tambah teman" pada Facebook, menambah nomor handphone pada Whatsapp, atau memiliki akun Tokopedia untuk berhubungan dengan penjual atau toko buku. Terkait proses, pengumpulan dan pemindahan dokumen komunikasi visual sampul buku: (1) pada fisik, mencari secara manual satu per satu di rak buku yang sebelumnya menncari kode di komputer pencari buku bila disediakan, meminta izin untuk difoto sampul bukunya dan lalu disimpat di tempat penyimpanan, seperti handphone atau flashdisk atau laptop; (2) pada virtual, mencari judul buku dengan mengetikan kata kunci di kolom pencarian di Facebook atau Tokopedia, meminta mengirimkan sampul buku di Whatsapp, lalu apabila didapatkan langsung tersimpan di handphone dan bisa dipindahkan ke flashdisk atau laptop.

\section{3). Karekter Bentuk Dokumen Komunikasi Visual Sampul Buku Fisik dan Digital}

Pada karakter bentuk dokumen komunikasi visual sampul buku fisik dan digital, digunakan ilmu fenomenologi sebagai alat analisis. Fenomenologi adalah ilmu tentang penampakan berarti ilmu tentang apa yang menampakan diri pada pengalaman subjek. 


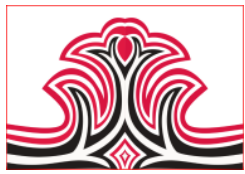

Hanya dengan berkonsentrasi pada yang tampak dalam pengalaman, maka esensi dapat dirumuskan dengan jernih (Adian, 2016). Pengalaman menggunakan alat panca indera-melihat, mencium, meraba, mengecap, dan mendengar - sebagai rangsangan yang dimiliki manusia. Ketika menganalisis karakter bentuk dokumen komunikasi visual sampul buku fisik dan digital, penulis menggunakan ransangan panca indera untuk mengalaminya.

Terdapat perbedaan penggunaan rangsangan panca indera saat menganalisis karakter bentuk dokumen komunikasi visual sampul buku fisik dan digital. Pada analisis karakter bentuk dokumen komunikasi visual sampul buku fisik, hanya bisa menggunakan rangsangan tiga panca indera, yaitu melihat, meraba, dan mencium. Walaupun, juga bisa dengan menggunakan panca indera mengecap. Tapi hal tersebut, terkesan tidak lazim, karena dilakukan dengan sengaja dan tidak alami seperti tiga panca indera sebelumnya. Pengalaman pada karakter bentuk dokumen komunikasi visual sampul buku fisik dengan menggunakan tiga panca indera, sebagai berikut: melihat, dipengaruhi dengan pencahayaan dan juga kualitas visual, apakah adanya terjadi kerusakan yang disebabkan dari percetakan, pengiriman, penyimpanan, dan durasi keberadaannya; meraba, dipengaruhi dengan kualitas kertas dan jenis mencetaknya, apakah kertasnya lembut, kasar, licin, dan halus; dan mencium, dipengaruhi dengan kuatnya bau yang menempel atau menjadi bagian pada kertas, seperti bau wewangian, kimia, buah, atau menyengat.

Pada analisis karakter bentuk dokumen komunikasi visual sampul buku digital, hanya bisa menggunakan rangsangan satu panca indera, yaitu melihat. Pengalaman pada karakter bentuk dokumen komunikasi visual sampul buku digital dengan menggunakan satu panca indera, sebagai berikut: melihat, dipengaruhi dengan pencahayaan dan juga kualitas alat untuk melihatnya, seperti handphone, laptop, atau komputer, apakah ketiga alat terssbut terdapat kerusakan. Bila terdapat kerusakan, akan memengaruhu kualitas tampilan dokumen komunikasi visual sampul buku digital. Namun, kualitas dokumen komunikasi visual sampul buku digital tetap baik dan tidak akan rusak. Berbeda dengan kualitas dokumen komunikasi visual sampul buku fisik yang bisa rusak karena termakan waktu. Kualitas dokumen komunikasi visual sampul buku digital abadi atau tidak akan rusak selama-lamanya.
Gorga : Jurnal Seni Rupa

Volume 10 Nomor 01 Januari-Juni 2021

p-ISSN: 2301-5942 | e-ISSN: 2580-2380

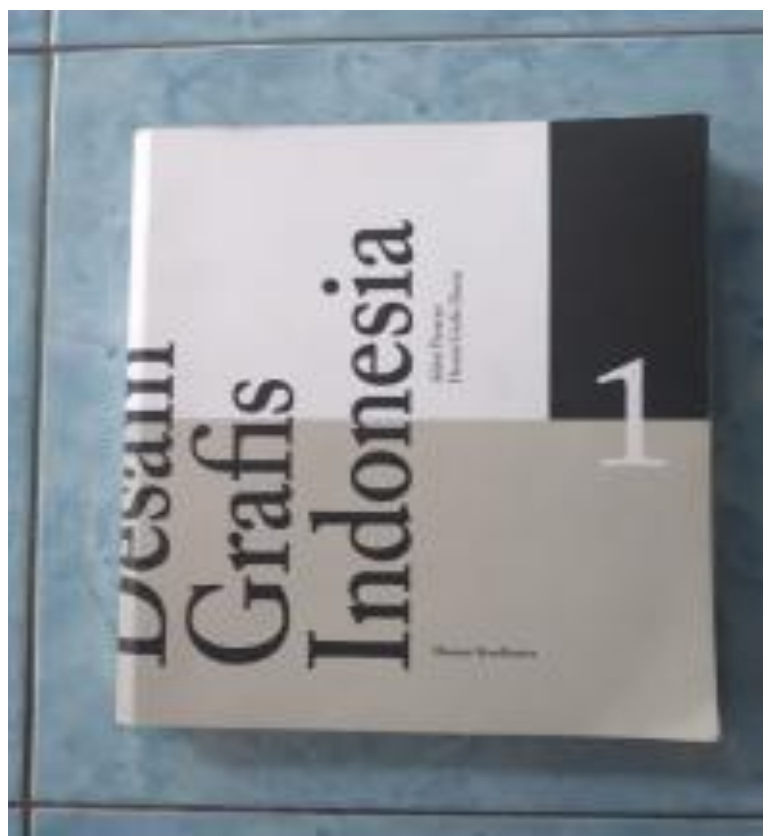

Gambar 1. Tampilan Dokumen Komunikasi Visual Publikasi Sampul Buku Fisik "Desain Grafis Indonesia" Melalui Teknik Pengumpulan Data dalam Metode Penelitian Etnografi Konvensional

Foto: Sujud Puji Nur Rahmat, Yogyakarta, 28 Mei 2021.

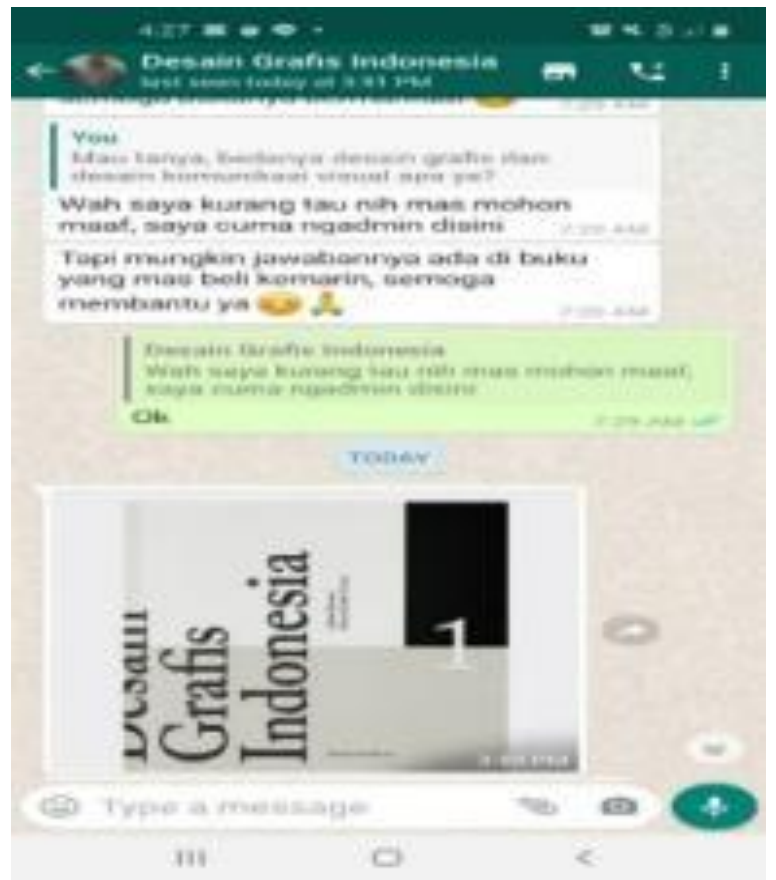

Gambar 2. Tangkap Layar Tampilan Dokumen Komunikasi Visual Publikasi Sampul Buku Digital "Desain Grafis Indonesia" di Whatsapp Desain Grafis Indonesia Store Melalui Teknik

Pengumpulan Data dalam Metode Penelitian Etnografi Virtual Tangkap Layar: Sujud Puji Nur Rahmat, Yogyakarta, 28 Mei 2021. 

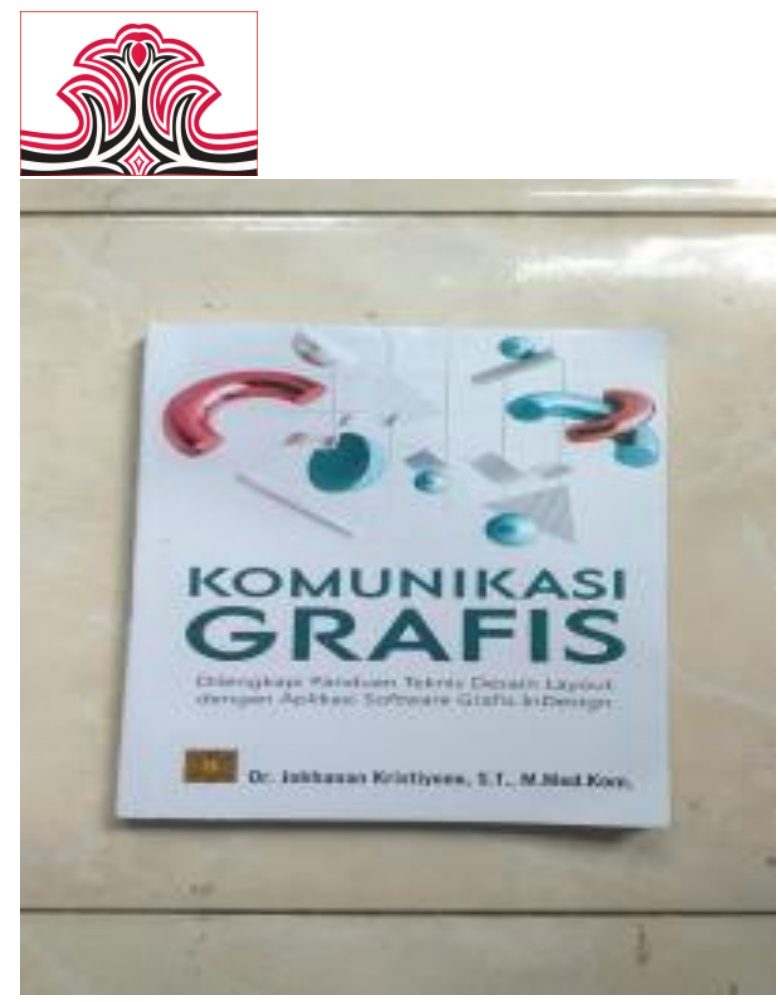

Gambar 3. Tampilan Dokumen Komunikasi Visual Publikasi Sampul Buku Fisik "Komunikasi Grafis" Melalui Teknik Pengumpulan Data dalam Metode Penelitian Etnografi Konvensional

Foto: Sujud Puji Nur Rahmat, Yogyakarta, 28 Mei 2021.
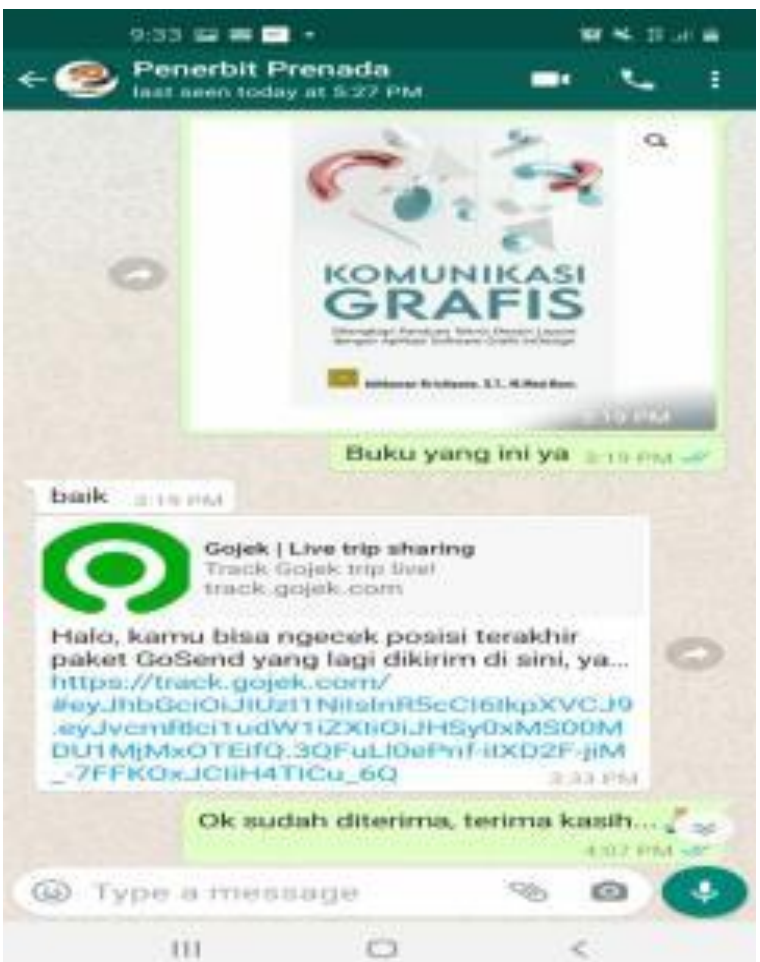

Gambar 4. Tangkap Layar Tampilan Dokumen Komunikasi Visual Publikasi Sampul Buku Digital "Komunikasi Grafis" di Whatsapp Pemasaran Penerbit Prenada Melalui Teknik Pengumpulan Data dalam Metode Penelitian Etnografi Virtual

Tangkap Layar: Sujud Puji Nur Rahmat, Yogyakarta, 28 Mei 2021.
Gorga : Jurnal Seni Rupa

Volume 10 Nomor 01 Januari-Juni 2021 p-ISSN: 2301-5942 | e-ISSN: 2580-2380

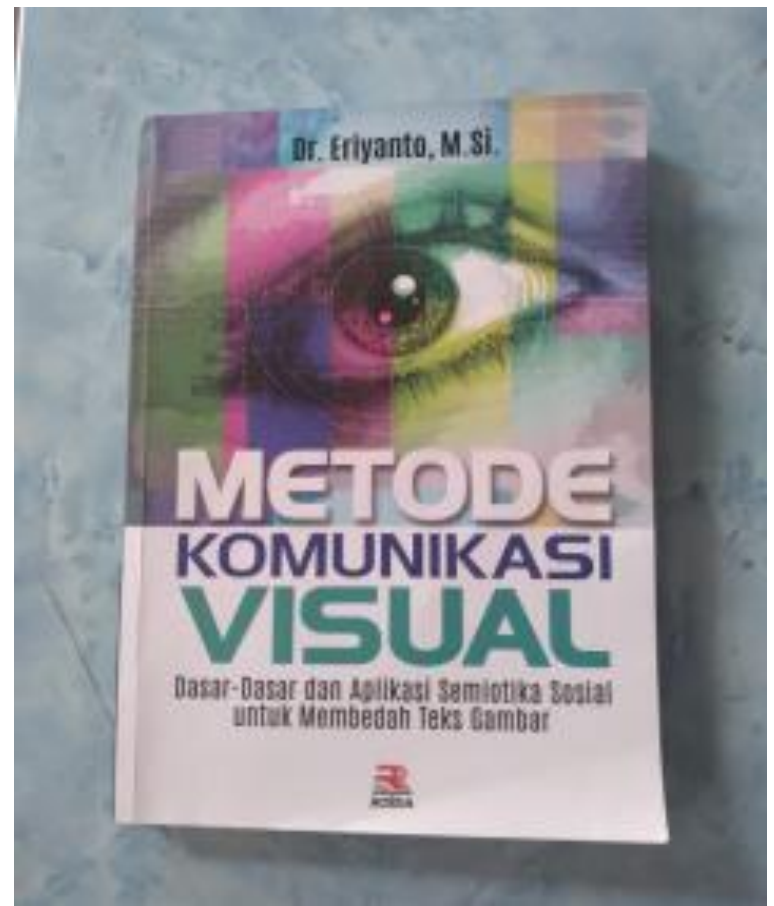

Gambar 5. Tampilan Dokumen Komunikasi Visual Publikasi Sampul Buku Fisik "Metode Komunikasi Visual" Melalui Teknik

Pengumpulan Data dalam Metode Penelitian Etnografi Konvensional

Foto: Sujud Puji Nur Rahmat, Yogyakarta, 28 Mei 2021.

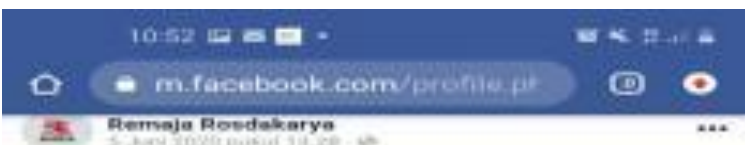

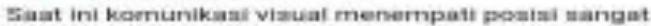
penting, apaingi ditambah dempan kehadiran medtis sosial (seperti instogram, Facebook. Twitter, YouTube. dan sebuguinya). Perkembangan ini membuat komunika el visual jauh lebih perting dan baryak digunakan dibandingkan dengan komunikasi tertulis. Kondisa ini menuntut keahlian dalam menganalisis leks

Klik link berikut, untuk informasi pernbeikan metalu Bibui.com

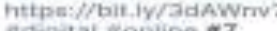

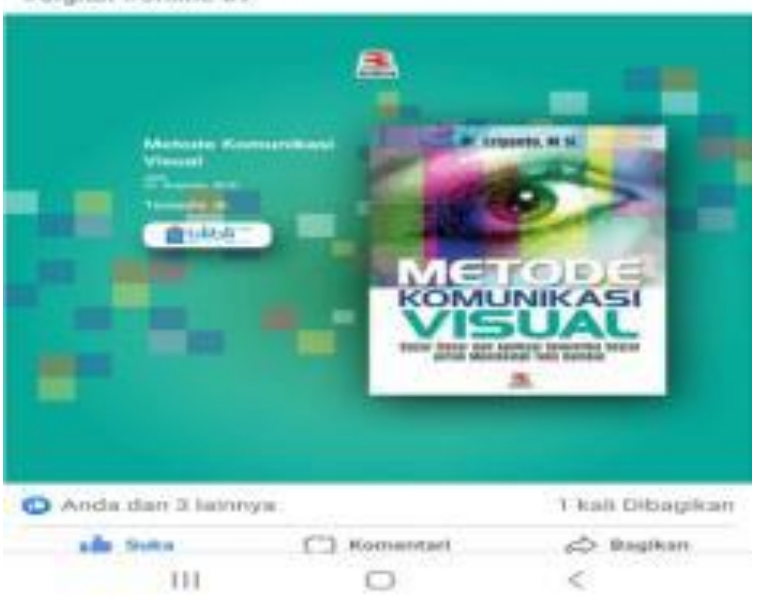

Gambar 6. Tangkap Layar Tampilan Dokumen Komunikasi Visual Publikasi Sampul Buku Digital "Metode Komunikasi Visual" di Facebook Penerbit Remaja Rosdakarya Melalui Teknik

Pengumpulan Data dalam Metode Penelitian Etnografi Virtual Tangkap Layar: Sujud Puji Nur Rahmat, Yogyakarta, 28 Mei 2021. 

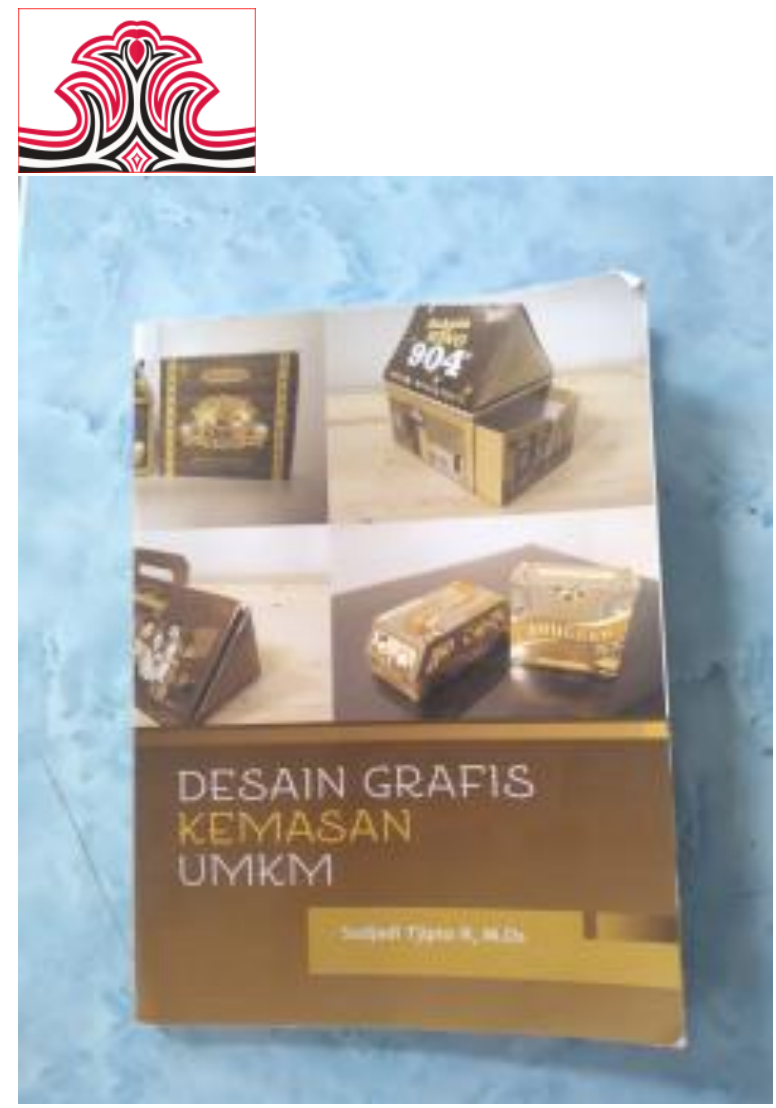

Gambar 7. Tangkap Layar Tampilan Dokumen Komunikasi Visual Publikasi Sampul Buku Digital "Desain Grafis Kemasan UMKM" Melalui Teknik Pengumpulan Data dalam Metode Penelitian Etnografi Konvensional

Foto: Sujud Puji Nur Rahmat, Yogyakarta, 28 Mei 2021

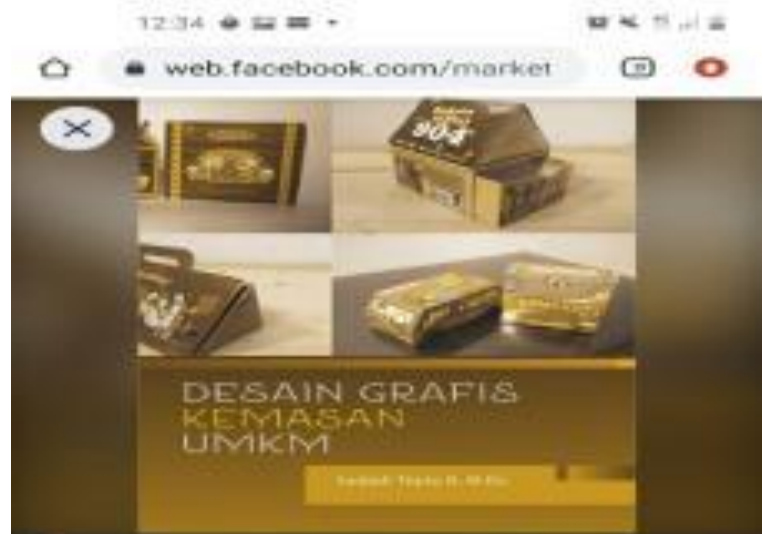

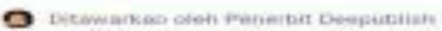

Buku Desain Grafs Kemasan

UMKM

Rp 87.000

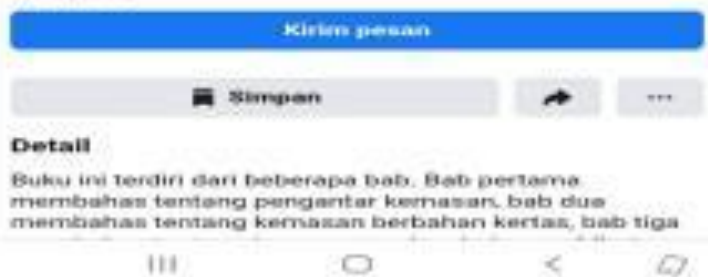

Gambar 8. Tangkap Layar Tampilan Dokumen Komunikasi Visual Publikasi Sampul Buku Digital "Desain Grafis Kemasan UMKM" di Facebook Penerbit Deepublish Melalui Teknik Pengumpulan Data dalam Metode Penelitian Etnografi Virtual

Tangkap Layar: Sujud Puji Nur Rahmat, Yogyakarta, 28 Mei 2021
Gorga : Jurnal Seni Rupa

Volume 10 Nomor 01 Januari-Juni 2021 p-ISSN: 2301-5942 | e-ISSN: 2580-2380

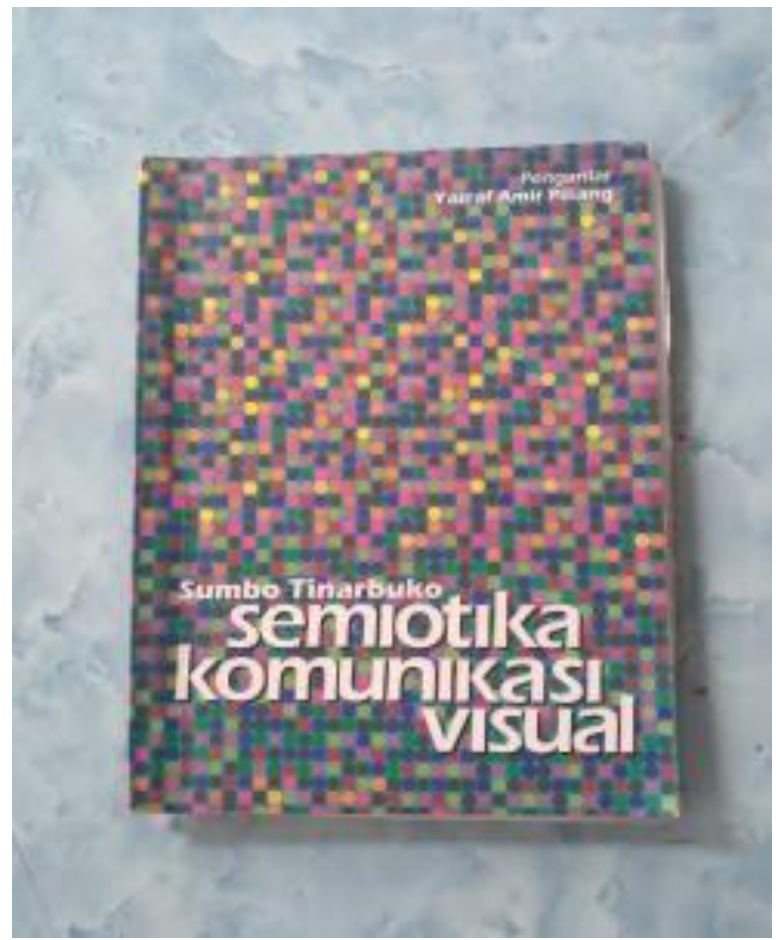

Gambar 9. Tangkap Layar Tampilan Dokumen Komunikasi Visual Publikasi Sampul Buku Digital "Semiotika Komunikasi Visual" Melalui Teknik Pengumpulan Data dalam Metode Penelitian Etnografi Konvensional

Foto: Sujud Puji Nur Rahmat, Yogyakarta, 28 Mei 2021.

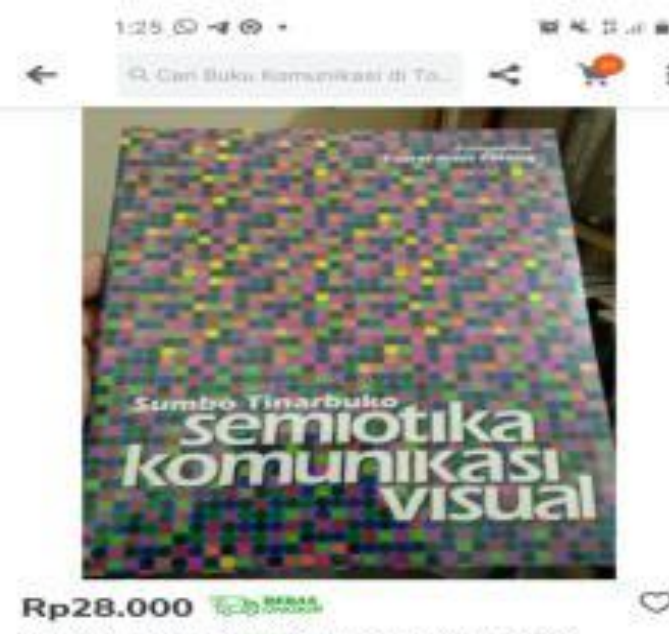

Serrikotika Komurikani Vinual - Suarnbo Tinaztouko

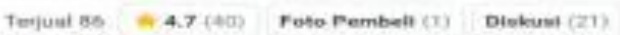

(C) Ade cashback hingga Rp10.000 Ada cashback hingga Fp10.000

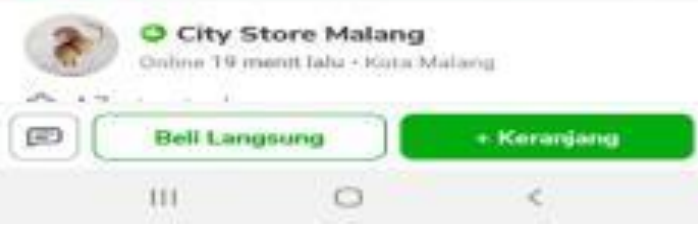

Gambar 10. Tangkap Layar Tampilan Dokumen Komunikasi Visual Publikasi Sampul Buku Digital "Semiotika Komunikasi Visual" di Tokopedia City Store Malang Melalui Teknik Pengumpulan Data dalam Metode Penelitian Etnografi Virtual Tangkap Layar: Sujud Puji Nur Rahmat, Yogyakarta, 28 Mei 2021. 


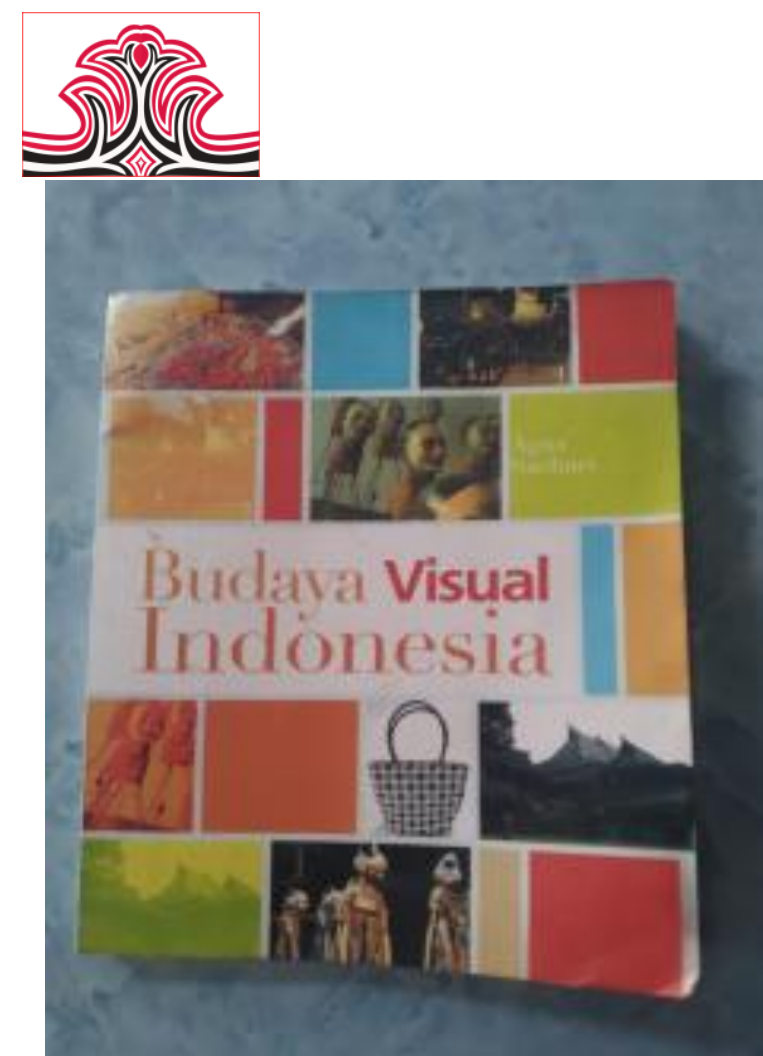

Gambar 11. Tampilan Dokumen Komunikasi Visual Publikasi Sampul Buku Digital "Budaya Visual Indonesia" Melalui Teknik Pengumpulan Data dalam Metode Penelitian Etnografi Konvensional

Foto: Sujud Puji Nur Rahmat, Yogyakarta, 28 Mei 2021.

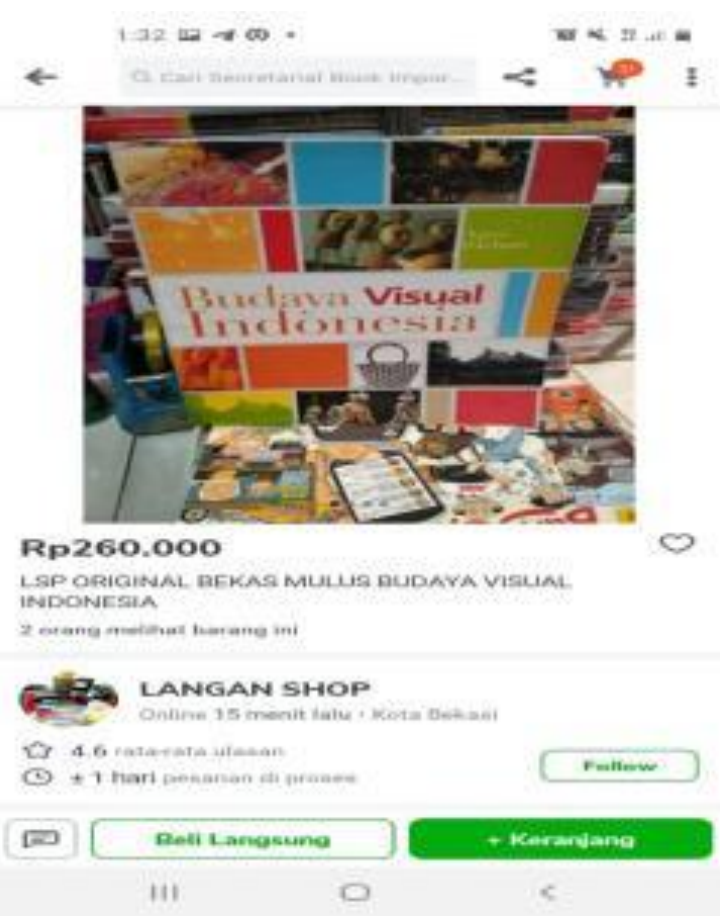

Gambar 12. Tangkap Layar Tampilan Dokumen Komunikasi Visual Publikasi Sampul Buku Digital "Budaya Visual Indonesia" di Tokopedia Langan Shop Melalui Teknik Pengumpulan Data dalam Metode Penelitian Etnografi Virtual

Tangkap Layar: Sujud Puji Nur Rahmat, Yogyakarta, 28 Mei 2021.

\section{Pembahasan}

Transformasi digital menciptakan dua pembahasan utama dalam sosial, yaitu sebab dan akibat. Pengertian sebab dan akibat, sebab dikarenakan transformasi sosial sebelumnya dan akibat menciptakan
Gorga : Jurnal Seni Rupa

Volume 10 Nomor 01 Januari-Juni 2021

p-ISSN: 2301-5942 | e-ISSN: 2580-2380

transformasi sosial selanjutnya. Pada sebab dikarenakan transformasi sebelumnya, kemajuan teknologi ini adalah terjadinya suatu transformasi sosial dalam masyarakat yang seringkali menimbulkan pula pola tingkah laku manusia serta terjadinya perubahan pola atau gaya hidup masyarakat pada umumnya (Septiarti, 1994). Pada akibat menciptakan transformasi sosial selanjutnya, ialah metode penelitian kualitatif yang berubah, mulai dari rencana penelitian, lapangan penelitian, cara pengamatan dan wawancara, dokumen komunikasi visual, hingga hasil penelitian yang serba digital tanpa bersentuhan dengan bendabenda fisik dan bertatap muka. Pada bagian ini, membahas dua transformasi sekaligus, yang berbasis transformasi sosial. Pertama, adalah transformasi digital; dan kedua, transformasi penelitian kualitatif.

Terdapat kontribusi temuan bagi ilmu pengetahuan dalam tulisan ini, yaitu pertama, berdasarkan perspektif sosial budaya menghasilkan teori dalam penyedian metode penelitian kepada generasi akan datang sesuai dengan perilakunya yang dapat bertahan hingga puluhan tahun, dan kedua, transformasi digital merupakan sebagai alternatif pilihan sebagai teknik pengumpulan data dalam metode penelitian kualitatif. Transformasi digital terkait penelitian kualitatif merupakan sebuah dorongan kepada peneliti muda generasi mendatang. Peneliti muda tersebut, adalah Generasi Z, yang lahir dan hidup selalu bersentuhan dengan teknologi bersumber internet yang menyediakan layanan jasa komunikasi visual berbasis media sosial, seperti Whatsapp, Facebook, dan Tokopedia. Transformasi digital merupakan sebuah alternatif pilihan selain hingga saat ini masih terdapat ruang penelitian kualitatif berbasis fisik atau tatap muka. Transformasi digital memudahkan generasi muda Generasi $\mathrm{Z}$ untuk menjadi seorang penelitian kualitatif. Melalui penelitian kualitatif berbasis transformasi digital, Generasi $\mathrm{Z}$ akan menjalani hidup sehari-hari dan menyelesaikan persoalan dengan berbasis penelitian kualitatif. Generasi Z, menurut Grail Research (2011), adalah generasi pertama yang sebenar-benarnya generasi internet (Rastati, 2018). Pada Generasi Z, merupakan generasi yang kelahirannya rentang waktu tahun 1995 hingga tahun 2010 (Christiani dan Ikasari, 2020). 


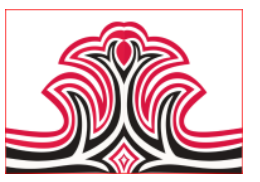

Generation $\mathbf{Z}$ dominates online searches for information on the post-Millennial generation Relative $U . S$. search volume of gerneration terrns (Coogle T)
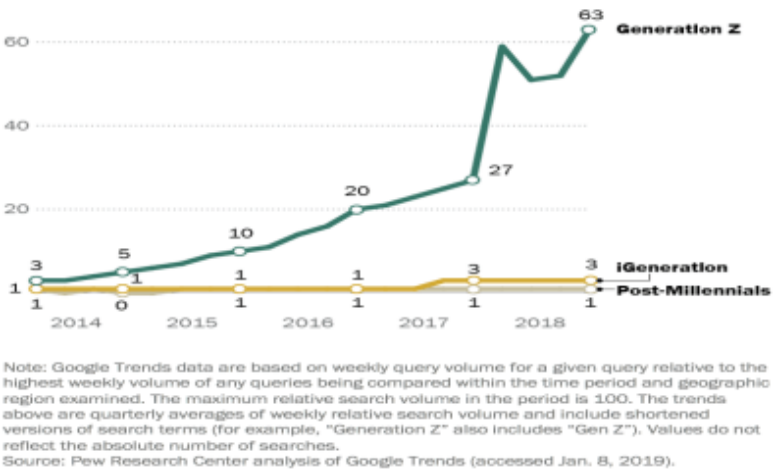
SEUTOE: Pow Research CON

Tabel 1. Generasi Z, Penggunaan Internet, dan Penelitian Onlinel Digital

Pew Research Center, Washington, 7 April 2021. (Brooke, 2021)

Akademisi, dalam menghasilkan penelitian diwajibkan dan ditentukan berdasarkan kaidah-kaidah akademis, seperti: epistemologi; metodologi dan metode penelitian; kualitatif dan kuantitaif; observasi, wawancara, dan (kajian) dokumen, dan sebagainya. Pada pandangan hasil penelitian, kaidah-kaidah akademis tersebut menjadi dasar dalam setiap pandangan hasil penelitian yang disampaikan para akademisi kepada msayarakat. Melalui kaidah-kaidah akademis, para akademisi, yang notabene peneliti ilmiah baik kualitatif maupun kuantitatif, menyampaikan hasil penelitiannya. Hasil penelitian yang baik, umumnya menunjukan pengalaman bagi seorang peneliti dan juga penemuan teknik pengumulan data terbaru dalam penggunaan metode penelitian kualitatif. Artinya, setiap penemuan terbaru berdasarkan metode penelitian kualitatif dibarengi dengan teknik pengumpulan terbaru.

\section{KESIMPULAN DAN SARAN}

\section{Kesimpulan}

Transformasi dengan Bahasa lugasnya merupakan mengubah bentuk dan nilai pada sesuatu. Mampu mengubah bentuk dan nilai pada dokumen komunikasi visual sampul buku. Pada penulisan ini mengahasilkan teori transformasi teknik pengumpulan data dalam metode penelitian kualitatif. Merupakan transformasi dokumen komunikasi visual sampul buku fisik menjadi digital. Tidak ada pembahasan yang penting dalam dokumen komunikasi visual sampul buku digital, sebab tidak terjadi transformasi.

Transformasi dokumen komunikasi visual sampul buku fisik menjadi digital menandakan sembilan hal penting. Pertama, mengubah bentuk dan nilai pola komunikasi
Gorga : Jurnal Seni Rupa

Volume 10 Nomor 01 Januari-Juni 2021

p-ISSN: 2301-5942 | e-ISSN: 2580-2380

dalam kehidupan sosial budaya masyarakat sebagai subjek penelitian. Kedua, mengubah bentuk dan nilai objek penelitian dokumen komunikasi visual sampul buku. Ketiga, mengubah bentuk dan nilai produksi, distribusi, dan kaidah bisnis perbukuan. Keempat, mengubah bentuk dan nilai jenis informasi yang diperoleh dan dianalisis. Kelima, mengubah bentuk dan nilai tata cara teknik pengumpulan data. Keenam, mengubah bentuk dan nilai kaidah metode penelitian kualitatif. Ketujuh, mengubah nilai pandangan bagi para peneliti kualitatif. Kedelapan, mengubah nilai pada generasi peneliti yang akan datang. Kesembilan, mengubah nilai padangan hidup umat manusia selanjutnya.

\section{Saran}

Penelitian ini, terbatas hanya pada objek dokumen komunikasi visual sampul buku digital dalam metode penelitian kualitatif perspektif sosial budaya. Virtual merupakan lapangan penelitian terbaru yang banyak tema-tema lainnya belum diteliti para peneliti kualitatif bidang desain komunikasi visual. Penelitian dokumen komunikasi visual digital bisa dikembangkan pada objek-objek lain pada bidang desain komunikasi visual, seperti gambar (ilustrasi), huruf dan tipografi, warna, komposisi, warna, layout, dan sebagainya. Perspektif yang berbeda dalam penelitian yang akan datang juga bisa dikembangkan dan digunakan, seperti psikologi, agama atau spiritual, kesehatan, ekonomi, politik, administrasi, dan disiplin ilmu lainnya. Mengenai teknik pengumpalan data, terdapat jenis yang lain, yaitu observasi atau wawancara dalam kualitatif, dan statistik dalam kuantitatif. Media komunikasi masyarakat berbeda juga bisa menjadi pertimbangan sebagai lapangan penelitian virtual, seperti Instagram, Traveloka, Twitter, Youtube, dan media sosial lainnya.

\section{DAFTAR RUJUKAN}

Adian, D.G. (2016). Pengantar Fenomenologi. Depok: Koekoesan.

Andarningtyas, N. (2020). Menyambut Era Transformasi Digital 2021. dihttps://www.antaranews. com/berita/1921172/menyambut-era-transform asi-digital-2021 (diakses tanggal 26 Mei 2021).

Anggito, A., \& Setiawan, J. (2018). Metodologi Penelitian Kualitatif. Sukabumi: CV Jejak.

Brooke, Auxier and Monica Anderson. (2021). A majority of Americans say they use YouTube and Facebook, while use of Instagram, Snapchat and TikTok is especially common among adults 30. https://www.pewresearch.org/internet/2021/0 
4/07/social-media-use-in-2021/ (diakses tanggal 07 Aprl 2021).

Christiani, L.C., \& Ikasari, P.N. (2020). Generasi Z dan Pemeliharaan Relasi Antar Generasi dalam Perspektif Budaya Jawa. Jurnal Komunikasi dan Kajian Media, 4(2), 85-105. http://dx.doi.org/10.31002/jkkm.v4i2.3326.

Hasanah, H. (2016). Teknik-teknik Observasi (Sebuah Alternatif Metode Pengumpulan Data Kualitatif Ilmu-ilmu Sosial). Jurnal at-Taqaddum, 8(1), 21-46.

Karmanis \& Karjono. (2020). Buku Pedeman Belajar: Metode Penelitian. Semarang: CV Pilar Utama.

Kistanto, N. H. (2018). Transformasi Sosial-Budaya Masyarakat Indonesia. Sabda: Jurnal Kajian Kebudayaan, 13(2), 169-178. https://doi.org/10.14710/sabda.13.2.169-178.

Nasrullah, R. (2016). Teori dan Riset Media Siber (Cybermedia). Jakarta: Prenadamedia Group.

Nugroho, A. (2020). New Normal, Momentum Transformasi Sosial Budaya. https://ugm.ac.id/id/berit a/19479-new-normalmomentum-transformasi-sosial-budaya (diakses tanggal 26 Mei 2021).

Mahmuddin. (2017). Transformasi Sosial Aplikasi Dakwah Muhammadiyah Terhadap Budaya Lokal. Makassar: Penerbit Alaudin Press.

Maulaa, M. (2020). 11 Bulan Pandemi Covid-19 Melanda Dunia, Berikut 6 Hal yang Perlu Anda Ketahui Saat Ini. https://www.pikiran-rakyat.c om/nasional/pr-01922691/11-bulan-pandemicovid-19-melanda-dunia-berikutberikut-6-halyang-perlu-anda-ketahui-saat-ini (diakses tanggal 26 Mei 2021).

Pratama, B.I. (2017). Etnografi Dunia Maya Internet. Malang: UB Press.

Putra, R.W. (2020). Pengantar Desain Komunikasi Visual dalam Penerapan. Yogyakarta: Andi Offset.

Rahmat, Sujud Puji Nur. (2021). "Karakter Penyebaran Sampul Buku”. Hasil Dokumentasi Pribadi: Mei 2021, Yogyakarta.

Rastati, R. (2018). Media Literasi Bagi Digital Natives: Perspektif Generasi Z di Jakarta. Kwangsan, 6(1), $60-73$. http://dx.doi.org/10.31800/jtp.kw.v6n1.p60--73

Sachari, A., \& Sunarya, Y.Y. (2001). Desain dan Dunia Kesenirupaan Indonesia dalam WacanaWacana Transformasi Budaya. Bandung: Penertbit ITB.

Sas. (2021). Transformasi Digital di Dunia Hari Ini. ditransformation.html\#: :text=Transform asi $\% 20$ digital $\% 20$ sering\%20digunakan $\% 20$ un2 Ountu,bisnis \%20internal\%2C\%20transformasi
Gorga : Jurnal Seni Rupa

Volume 10 Nomor 01 Januari-Juni 2021

p-ISSN: 2301-5942 | e-ISSN: 2580-2380

\%20menjadi\%20mungkin (diakses tanggal 26 Mei 2021).

Sakti, M. N. (2020). Moslem Social Media: Argumen Islam Terhadap Fenomena Sosial Media di Era Industri 4.0. Jakarta: PT Elex Media Komputindo.

Septiarti, S. W. (1994). Tranformasi Sosial Masyarakat dalam Perspektif StrukturalimseFungsionalisme Suatu Tinjauan Sosiologis. Cakrawala Pendidikan, 13(3), 127138. https://doi.org/10.21831/cp.v3i3.9153.

Soewardikoen, D. W. (2019). Metodologi Penelitian Desain Komunikasi Visual. Yogyakarta: Kanisius.

Tinarbuko, S. (2012). Semiotika Komunikasi Visual. Yogyakarta: Jalasutra.

Wasitaatmadja, F. F. (2020). Etnografi Hukum: Budaya Hukum Masyarakat Cina Jelata. Jakarta: Kencana. 